\title{
Anatomy of the reproductive tract of the female muskox (Ovibos moschatus)
}

\author{
J. Rowell* $\ddagger$, K. J. Betteridge $\$$, G. C. B. Randall† and J. C. Fenwick* \\ ${ }^{*}$ Department of Biology, University of Ottawa, Ottawa, Ontario and $\uparrow$ Animal Diseases Research \\ Institute, Agriculture Canada, PO Box 11300, Station H, Nepean, Ontario K2H 8P9, Canada
}

\begin{abstract}
Summary. Reproductive tracts from 23 female muskoxen were collected from the Canadian high arctic during annual native muskox hunts. Twenty tracts were collected during the late breeding season and the last third of pregnancy or anoestrus, with 3 additional specimens taken just before the breeding season in August.

The non-gravid muskox uterus was very similar to that of sheep and goats except for two features found in parous muskoxen. The first was endometrial pigmentation found only in the caruncles and associated with a dense collection of lipofuscin granules in the endometrial stroma. The second was a prominent $5 \mathrm{~mm}$ deep band of muscular tissue protruding from the antimesometrial border of the uterine horns throughout most of their length. The pregnant uterus and the fetal membranes of the muskox resembled homologous structures in domestic ruminants. However, there was no morphological evidence of a corpus luteum during late pregnancy, apart from a luteal scar in the ovary ipsilateral to the pregnant horn. Of the 4 females collected at the end of the breeding season, 2 lactating females were apparently not cyclic while 2 others had more than one CL, suggesting that they had undergone at least 2 cycles without conceiving or remaining pregnant.
\end{abstract}

\section{Introduction}

The muskox (Ovibos moschatus) is indigenous to arctic North America and Greenland and is classified in the Family Bovidae, Subfamily Caprinae, Tribe Ovibovini, Genus Ovibos (Simpson, 1945). Analyses of serum proteins (Moody, 1958) and fatty acids (Chisholm \& Hopkins, 1957) have suggested a phylogenetic relationship between muskoxen and sheep, but the muskox also has characteristics in common with goats, cattle and bison (Tener, 1965).

Most information on muskox reproduction has been obtained from behavioural studies or observations of calf crops. There is a distinct breeding season in the late summer or early fall (Tener, 1965; Gray, 1973; Smith, 1976) with bulls exhibiting rutting behaviour, e.g. the acquisition and defence of harems, in the second half of July (Gray, 1973; Smith, 1976). Cows are seasonally polyoestrous with a cycle length of 21 days and oestrus lasting $12 \mathrm{~h}$ in captive animals (J. Bourque, cited by Gray, 1973). Gestation lasts 249-254 days (Alendal, 1971) with a single calf being delivered between March and June, although more frequently in April and May (Gray, 1973; Tessaro et al., 1984). It has been commonly held that cows only calve in alternate years (Tener, 1965), presumably undergoing a lactational anoestrus following calving. However, current information suggests that

\footnotetext{
\$Present address: Department of Veterinary Anatomy, Western College of Veterinary Medicine, University of Saskatchewan, Saskatoon, Saskatchewan, Canada S7N 0W0.

$\S$ Present address: Department of Biomedical Sciences, Ontario Veterinary College, University of Guelph, Guelph,

Ontario, Canada N1G 2W1.
} 
breeding can, and does, occur in successive years in parts of the high arctic and may depend, in part, on the animal's condition (Tessaro et al., 1984).

The only published accounts of the reproductive anatomy of the female muskox appear to be those of Lönnberg (1900a, b) and Sack \& Ballantyne (1965). This paper describes the anatomy of the reproductive tract of female muskoxen using descriptions given for domestic ruminants as a guide. Some of the information has been briefly presented previously (Rowell \& Betteridge, 1984).

\section{Materials and Methods}

Reproductive tracts were collected from 23 muskoxen in the Grise Fiord region of the eastern arctic by accompanying native hunters on their annual hunts in 1977 and 1978. Weather conditions and the 24 h darkness of winter restricted hunting to the months of October and March. Three of the tracts were collected in August when the temperature was above $0^{\circ} \mathrm{C}$ and there was continuous daylight. The distribution of specimens by season and age class is shown in Fig. 1 .

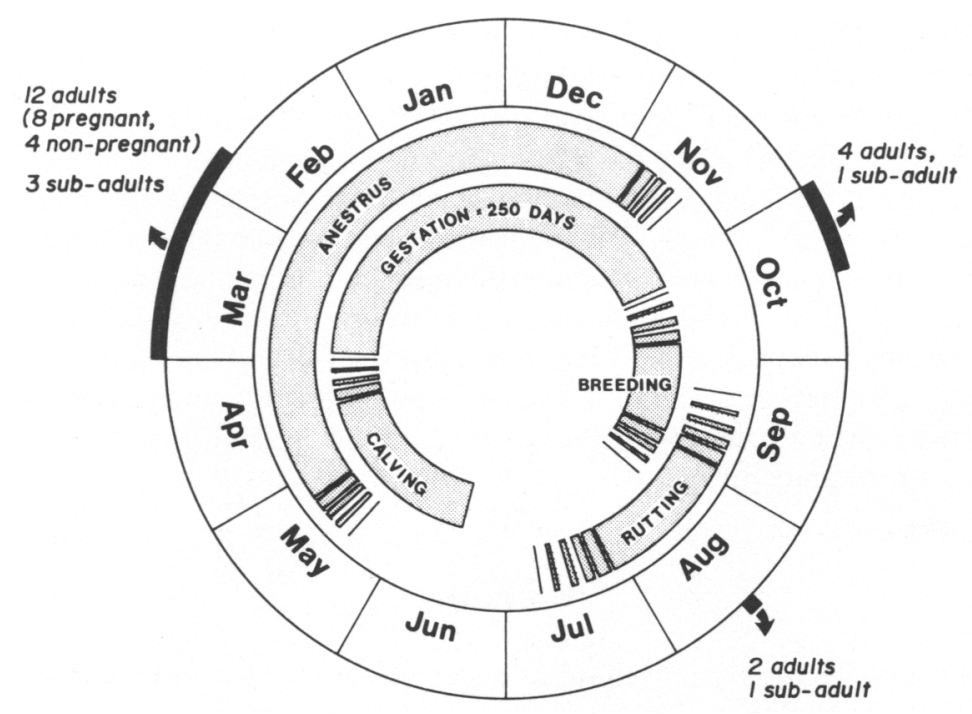

Fig. 1. Distribution of collected specimens shown in relation to season and reproductive cycle.

Tracts were removed by cutting caudal to the external os of the cervix and then through the broad ligaments as close to the body wall as possible. The following tissues were fixed from 13 of 23 tracts; small pieces from the uterine horn (cut just above the external bifurcation), the oviduct, the cervix, the vagina, and entire ovaries (bisected longitudinally). The tissues were fixed in acetic acid-commercial formalin-ethyl alcohol (19:10:30\%, by vol.) and distilled water ( $50 \%$ by vol.), chosen because of its low freezing point. Before adding the tissues, the fixative was warmed to $\sim 37^{\circ} \mathrm{C}$. The other 10 tracts, and fetuses removed from pregnant tracts, were frozen and remained so during transport south. Ambient temperatures in the winter $\left(-40\right.$ to $\left.-50^{\circ} \mathrm{C}\right)$ adversely affected the quality of fixation of some specimens since penetration of the tissues was slow and the deeper layers of many tissues froze before fixation was complete. The August trip alleviated most of these problems and all the tissues from this collection were adequately fixed.

In the laboratory, the non-pregnant tracts were thawed in warm saline, $\sim 37^{\circ} \mathrm{C}$, weighed, measured, and photographed before dissection. Five tracts collected in October were flushed for ova or embryo recovery by methods routinely used for cattle (Betteridge et al., 1980). Fixed tissues were embedded in paraffin wax using routine procedures except that dehydration times were lengthened 1.5 times and toluene was substituted for xylene as the clearing agent to reduce hardening of the tissues. All sections were cut at $6-10 \mu \mathrm{m}$ and serial sections were made of all the ovaries, mounting every tenth section. Tissues were stained with Gill's haematoxylin and eosin (Fisher Scientific) but representative sections of each were stained with Masson's trichrome (Putt, 1972). The staining techniques used for the identification of lipofuscins were Perl's Prussian blue reaction (Lillie, 1965), Oil red O (Drury \& Wallington, 1967), 
Masson-Fontana and Schmorl's reaction (using bleached and unbleached sections) and the Long-Ziehl-Neelsen test (Drury \& Wallington, 1967).

Fetal weights and crown-rump measurements were used as a guide for assessing fetal age in conjunction with the criteria of Evans \& Sack (1973) and the fetal growth rate formula of Huggett \& Widdas (1951) which is known to be only approximate (Guy, 1983).

\section{Results}

\section{The parous non-gravid uterus}

Ten uteri, collected from mature cows during 3 different sampling times, were similar in appearance and size and were assumed to be parous non-gravid tracts. the average weight of these tracts was $117.9 \mathrm{~g}$ (range $94.9-178.7 \mathrm{~g}$ ). The body of the bicornuate uterus measured $1.5-2.0 \mathrm{~cm}$ from the internal os to the septum. The horns, joined by a single intercornual ligament, were coiled 1-1.5 times while tapering towards the utero-tubal junction. They averaged $26 \mathrm{~cm}$ in length (range $17-39 \mathrm{~cm}$ ) measured along the greater curvature. The coiled transiverse arteries were prominent just beneath the serosal surface as reddish striations. A muscular band of tissue about $5 \mathrm{~mm}$ deep ran along the antimesometrial border of the uterus, originating at the bifurcation of the horns and disappearing a short distance proximal to the utero-tubal junction. In 2 of 10 specimens it appeared to be continuous with the intercornual ligament (Figs $2 \& 3$ ).

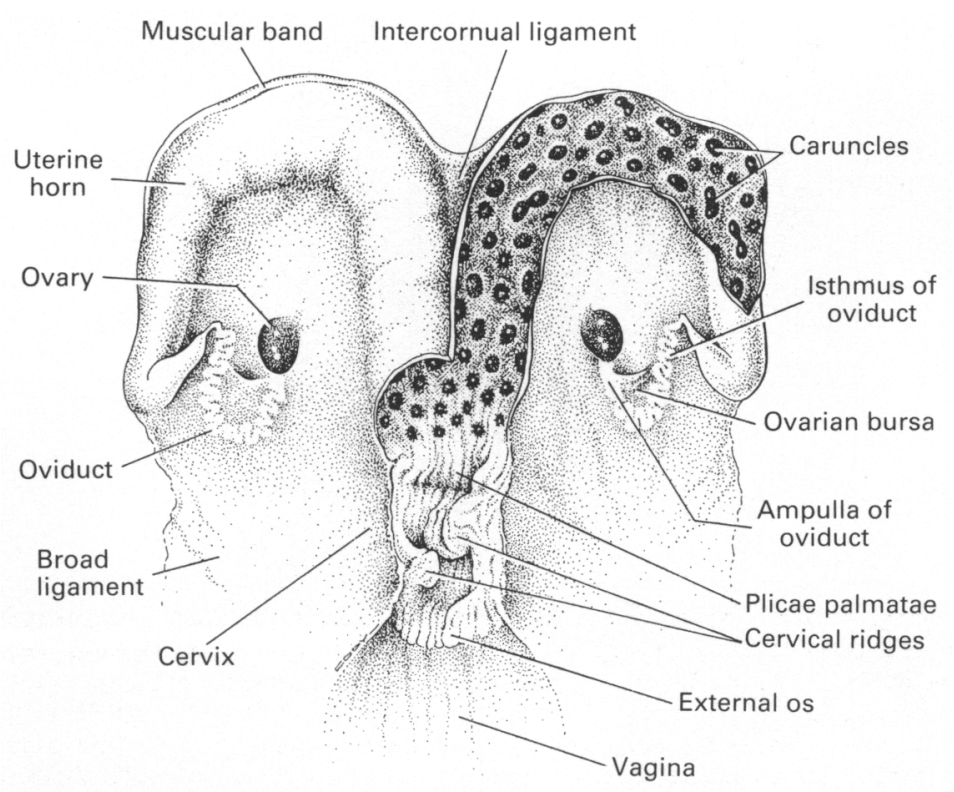

Fig. 2. A composite drawing of the uterus of a mature, non-pregnant muskox. The cervix, body, and right uterine horn have been opened to reveal internal structures; the uterine horns have been straightened to clarify the illustration and the bursa reflected to reveal the ovaries.

Internally, the uterus contained 4 roughly longitudinal rows of caruncles extending from the body into both horns. The caruncles varied between $4 \times 3 \mathrm{~mm}$ to $8 \times 4 \mathrm{~mm}$ in dimension and fusion of two (occasionally more) was common. Those near the cervix and the utero-tubal junction were generally smaller in size than the rest. With the exception of the smaller ones at the extremities 

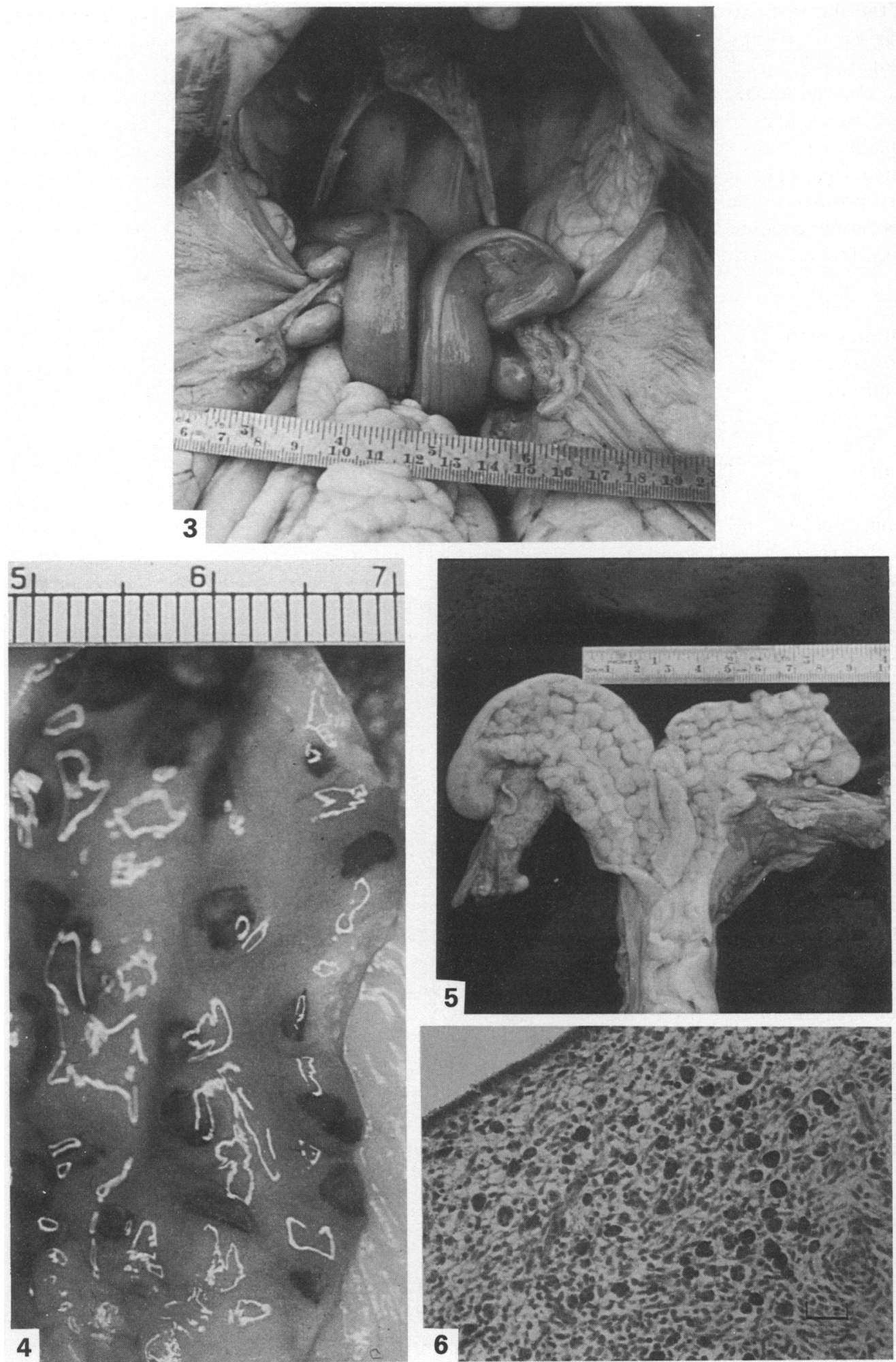
of the uterus, all caruncles contained a dark pigment in their central depression. No similar pigment was seen in the intercaruncular areas. The average number of caruncles per uterine horn was 80 (range 75 95) (Figs $2 \& 4$ ).

The endometrium was lined by columnar epithelium and, with the exception of the caruncles, was highly glandular. Large, pigmented cells were found in the caruncular connective tissue, usually concentrated beneath the epithelium (Fig. 6). This pigment was identified as lipofuscin, being negative for haemosiderin in the Perl's Prussian blue test, positive for lipids with Oil red $\mathrm{O}$ and also positive in the Masson-Fontana, Schmorl's and the Long-Ziehl-Neelsen tests for acid-fast lipofuscin. Both the Masson-Fontana and the Schmorl's reaction remained positive when repeated with bleached sections, indicating that the pigment granules were not melanin.

Uterine muscle layers were arranged like those of cattle and sheep and consisted of a longitudinal (thin) and circular (thick, inner) smooth muscle layers. The muscular band of tissue on the antimesometrial border appeared, histologically, to be a fold of the outer longitudinal layer. Cross-section of the central portion of this band revealed a network of connective tissue which was continuous with a distinct connective tissue layer separating the longitudinal and circular layers of the myometrium (Fig. 7).

The oviduct was thin-walled and only moderately coiled, with the isthmus being more tortuous than the ampulla. The fimbria attached at one end to the mesovarium near the caudal edge of the ovarian hilus and, at the other pole, became continuous with the ovarian bursa, which formed a roomy pocket. There was no evidence of a muscular ring or of villi at the utero-tubal junction.

The epithelium was generally high columnar with cilia predominating in the fimbria and lower portions of the ampulla. The mucosa of the oviduct formed primary and secondary folds, folding being most elaborate near the ostium abdominale. In this portion of the tube the muscle wall was greatly reduced, being composed mainly of a band of circular smooth muscle fibres and vascular elements. The muscularis thickened towards the isthmus.

The cervix (Figs 8-10) was firm and thick walled, averaging $8.0 \mathrm{~cm}$ in length (range $7 \cdot 2-9.0 \mathrm{~cm}$ ). The external os was prominent and, with some individual variation, enveloped in folds arising from the anterior vaginal wall. In 20 of the 23 specimens there was a projection resembling an epiglottis which protruded from the ventral border of the external os and covered the entrance to the cervix. In the 3 cows collected in August (just before the breeding season) this structure was noticeably swollen.

Dissection of the cervix revealed a complex cervical canal which, when sectioned through a dorsal plane, appeared as a prominent ' $S$ ' shape and, when sectioned sagittally, showed 3 or 4 ridges or annular rings, $1.5-2.0 \mathrm{~cm}$ apart. The first and second ridges (the first ridge being continuous with the external os) were the most prominent and complex (Fig. 8). The cervical mucosa was elaborately folded into very complex plicae palmate with the mucosal folds inclined towards the uterine end producing many branched furrows. The internal os was uniformly inconspicuous and took the form of a rosette with a small annular ring.

The cervical mucosa was lined by a non-ciliated secretory, columnar epithelium. There was no evidence of coiled tubular glands but the mucosa was elaborately folded into secondary and tertiary folds. The musculature was thick, less uniform than myometrium and contained a high proportion of collagen fibres.

Fig. 3. The uterus, in situ, of a parous muskox (ventral aspect). The scale lies cranial to the uterine horns and is in inches (top) and $\mathrm{cm}$ (bottom).

Fig. 4. The endometrium from the uterine horn of a parous, non-pregnant muskox. The dark pigmentation is located only on the caruncles.

Fig. 5. The opened uterus of a non-parous muskox showing the lack of endometrial pigmentation.

Fig. 6. Lipofuscins in the endometrial stroma of a mature non-gravid uterus. Oil red $\mathrm{O}$, bar $=30 \mu \mathrm{m}$. 

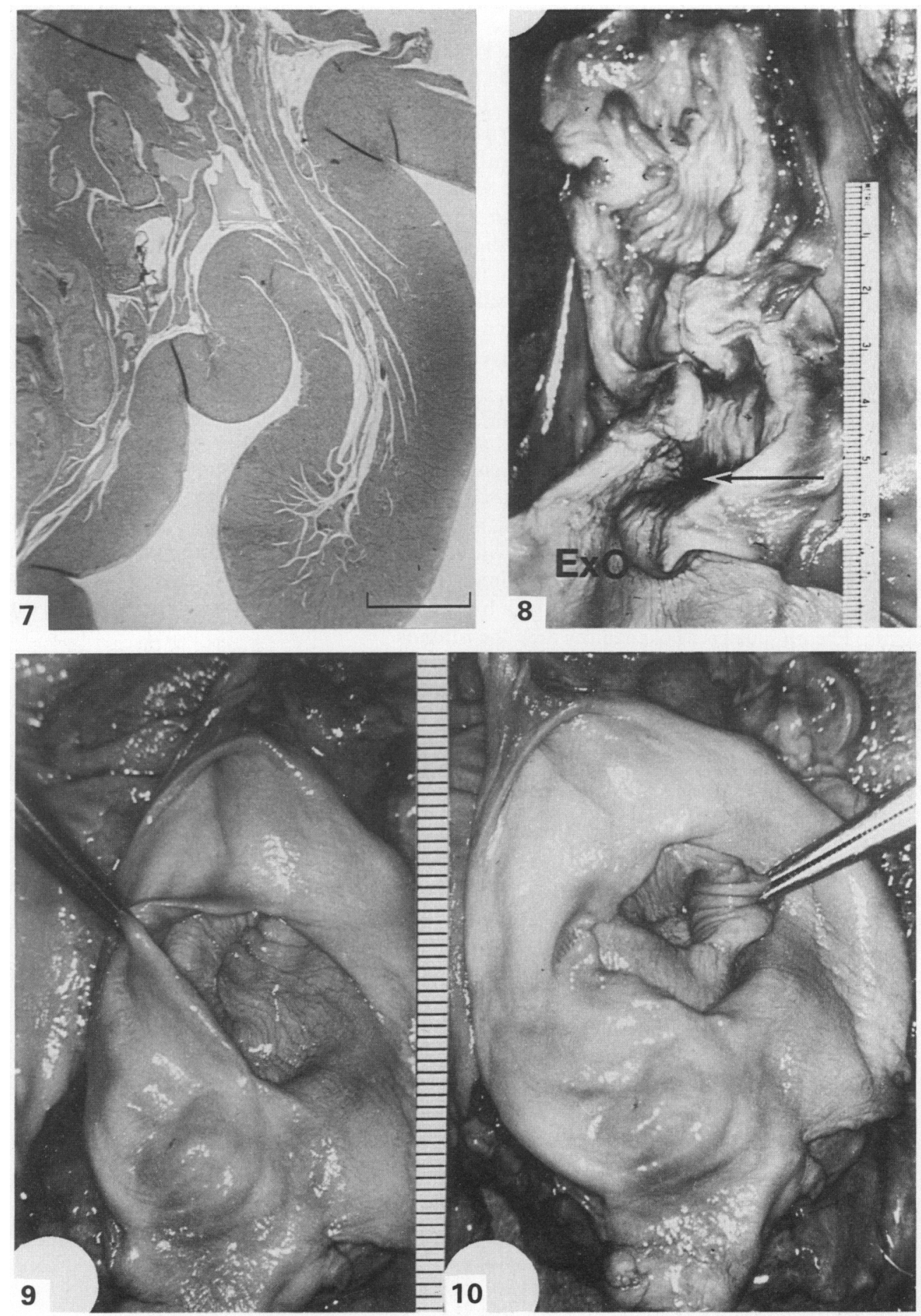


\section{The non-parous uterus}

Five uteri were judged to be from non-parous females based on the following criteria. Although similar to the parous, non-gravid tracts in many respects, non-parous tracts were smaller, with an average weight of $49.4 \mathrm{~g}$ and an average horn length of $14 \mathrm{~cm}$ (range 10-17 cm). Coiled arteries were visible just beneath the serosal surface of the horns but did not produce the prominent striations seen in the parous animals. Except for the ovarian artery, which was intimately coiled around the ovarian vein in all specimens, major arteries and veins exhibited none of the intricate coiling found in the parous tracts. The non-parous tracts lacked the prominent muscular band along the antimesometrial border and although the caruncular count approximated that of the parous animals, the caruncles were devoid of pigment (Fig. 5).

Non-parous tracts were histologically similar to those of the adults except for the absence of lipofuscin granules.

\section{The gravid uterus}

Of the 8 gravid uteri, all taken during the last third of pregnancy, 4 were collected with the fetus in situ; in the other 4 the fetuses had been removed by the hunters. Based on fetal characteristics, the stage of pregnancy was estimated to be 3-7 weeks before parturition. At this stage of pregnancy the uterus was greatly enlarged and located ventrally in the abdominal cavity. Each horn had only a single coil and the gravid horn was obviously the larger, even in those from which the fetus had been removed. Pregnancies were equally divided between the left and the right horns.

The placenta extended into both horns and involved all of the caruncles except for a few of the smaller distal ones. The septum had become quite enlarged and had placentomes on both sides. The placentomes were pedunculate and ellipsoidal in shape, having a shallow central depression with a low rim around the edge. There was considerable variability in size and shape of the caruncles, the largest of which were generally $8-9 \mathrm{~cm}$ in diameter and found in the region of the fetus. There were about 75-100 carcuncles per horn and small areas of adventitious cotyledonary tissue were common.

The fetal membranes separated easily from the maternal tissue and consisted of an amnion surrounding the fetus and an extensive allantois within the chorion. The allantois crossed over a portion of the amnion, forming a ' $T$ ' shape at the urachus. Fetal villi were found on the amniochorion as well as the allantochorion with the latter containing the greater number of placentomes. A necrotic tip was found at both extremities of the allantochorion.

Small, yellow-white cysts were found on the endometrial tissue of all pregnant uteri, on, or close to, a caruncle (Fig. 11). They varied from spheroidal to long and slender in shape. Some cysts

Fig. 7. Cross-section through the antimesometrial border of the uterine horn of a parous, nonpregnant muskox. The muscular band is shown as a prominent fold of the outer muscular layer enclosing capillaries and connective tissue elements. $\mathrm{H} \& \mathrm{E}$; bar $=1 \mathrm{~mm}$.

Fig. 8. The cervix from a mature non-pregnant muskox, opened dorsally, ExO, external os; the darkened area (arrow) is part of the cervical canal which dips ventrally.

Fig. 9. The external os of the cervix from a mature, non-pregnant muskox collected in March. The forceps are lifting a small fold in the vaginal tissue which partly surrounds the opening to the cervix. In this specimen the tissue flap was found on the dorsal wall. Scale to the right is in $\mathrm{mm}$.

Fig. 10. The same specimen depicted in Fig. 9 showing the epiglottis-like structure at the cervical opening. There is marked variation in both the shape and position of this structure ranging from pendulous to almost vestigial. The specimen depicted here was considered intermediate. Scale in $\mathrm{mm}$. 

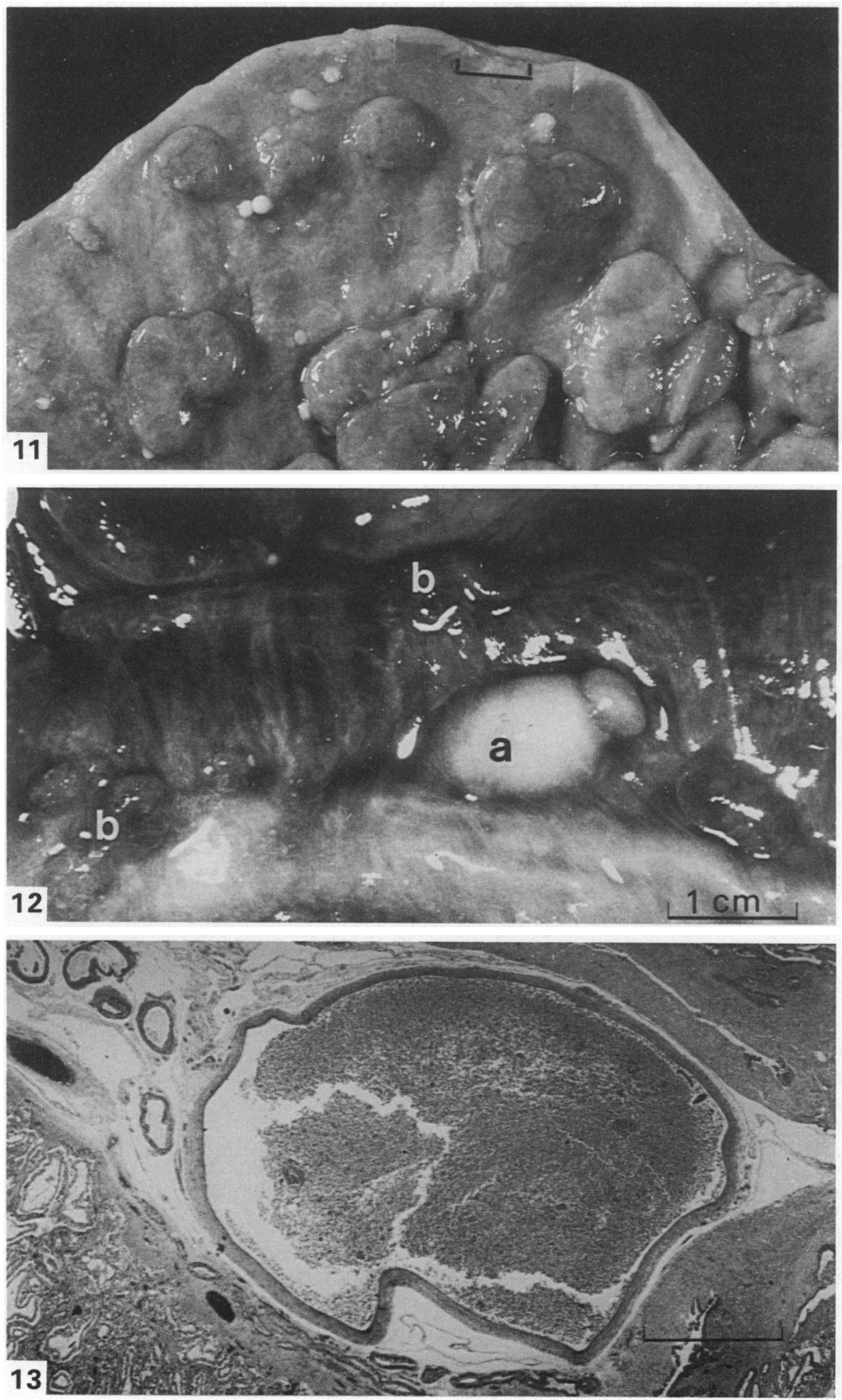
protruded noticeably whilst others formed low amorphous masses. The largest cyst measured $13 \times 15 \mathrm{~mm}$ (Fig. 12). The cysts contained cellular debris surrounded by a thick connective tissue capsule lined with epithelium (Fig. 13).

Histological interpretation of placental structure was difficult because the specimens had been frozen. However, the available material indicated that placentation followed the ruminant pattern with the branching villi of the chorion lodged deep in maternal crypts and surrounded by projections of maternal tissue (Fig. 14). Fetal capillaries were in close apposition with the chorionic epithelium which contained large binucleate cells (Fig. 15). Pools of extravasated blood were found at the base of the fetal villi and were presumably of maternal origin. Some erosion of maternal tissue was evident in this region but the full extent of this could not be determined. The trophoblastic cells were filled with an orange-brown pigment in the area of the extravasated blood.

\section{The ovaries}

The ovaries in the non-pregnant animal were almond-shaped and were attached along one edge to the dorsal surface of the broad ligament at about the level of the external bifurcation of the uterine horns. They averaged $20.3 \mathrm{~mm}$ in length $\times 14.0 \mathrm{~mm}$ in width $\times 8.3 \mathrm{~mm}$ in depth. Numerous, small, non-protruding antral follicles were visible on the ovarian surface of the March and October specimens. In August, all 3 specimens had large follicles that protruded from the ovarian surface. The 2 adult cows each had a single large follicle with diameters of $12 \mathrm{~mm}$ and $17 \mathrm{~mm}$ respectively. The immature cow had a large follicle in each ovary ( 7 and $9 \mathrm{~mm}$ ). In the ovaries of these 3 cows there were neither recently regressed corpora lutea nor any indication of a recent ovulation.

The ovaries were covered in a thin 'germinal' epithelium overlying a collagenous tunica albuginea of varying thickness. The cortical layer was relatively thin and covered the medulla except in the region of the hillus. the medulla occupied the greater portion of the ovary. In general the primordial and primary follicles were found just under the tunica albuginea. Secondary follicles were deeper in the cortex and Graafian follicles were found throughout the ovary. The granulosa of the Graafian follicles commonly contained numerous, prominent 'Call-Exner' bodies. Follicular atresia appeared to occur at all stages of follicle development in parous and non-parous animals.

The ovaries of 2 mature, lactating and apparently healthy cows were collected in October and showed no evidence of follicular activity or corpora lutea (CL). Corpora lutea were found in the other 3 specimens collected in late October, and 2 of these 3 cows had multiple CL. One of these, an adult, had two easily recognized CL in the right ovary. The second adult had a large CL measuring $14 \mathrm{~mm}$ in diameter and a second, smaller CL, both in the left ovary (Fig. 16) while her right ovary had a recent ovulation with a stigma on the surface connecting with a large corpus haemorrhagicum. Because these specimens were collected frozen, it was impossible to age the CL histologically. The uterine and oviducal flushes yielded neither ova nor embryos, and so there was no means of determining whether or not the animals were pregnant, and no information was available on their lactational state.

Fig. 11. Endometrial cysts adjacent to and in between the maternal caruncles. (This specimen is an involuting uterus from a western arctic collection. It is included here to illustrate the appearance of these cysts found in all tracts during late pregnancy.) Scale bar (at top) $=1 \mathrm{~cm}$.

Fig. 12. Endometrial surface of a maternal caruncle showing an endometrial cyst (a). The nodules (b) appeared as areas of extra placental tissue. These were found almost exclusively in association with the maternal caruncles. The specimen was from a pregnant muskox collected in March.

Fig. 13. Cross-section of an endometrial cyst. The cyst was surrounded by a connective tissue capsule lined by columnar epithelium and was filled with cellular debris. H \& E; bar $=1 \mathrm{~mm}$. 

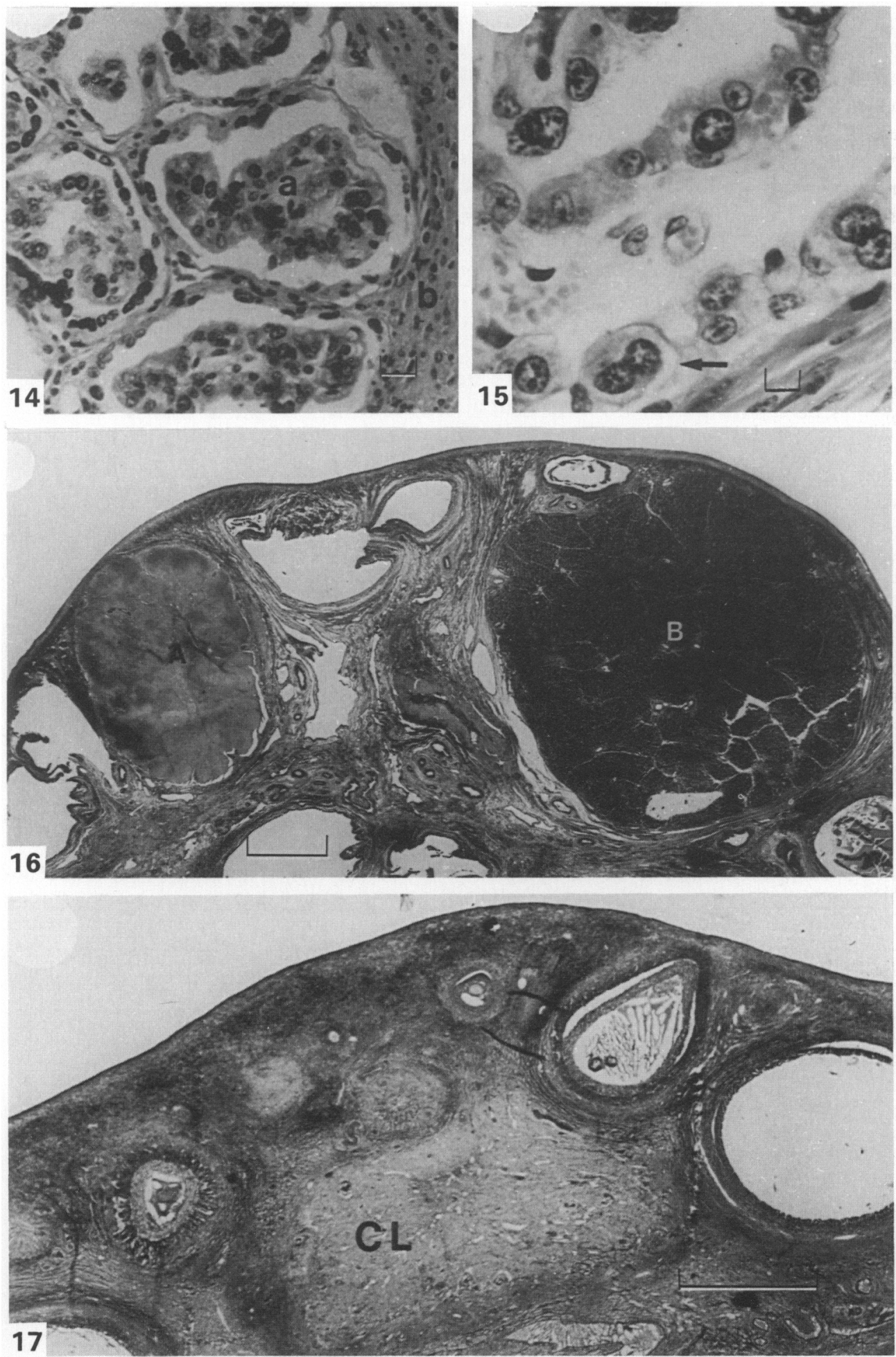
In all the pregnant animals, both ovaries were laterally flattened and elongated, measuring approximately $26 \mathrm{~mm} \times 12.5 \mathrm{~mm} \times 5.1 \mathrm{~mm}$. When cut 4 times along the longitudinal plane, the cortex, medulla, and small antral follicles were visible but there was no sign of a discrete functional or regressing $\mathrm{CL}$ of pregnancy. However, in 7 of the 8 pairs of ovaries histological examination revealed a single regressed CL (Fig. 17), consistently in the ovary ipsilateral to the pregnant horn. These luteal scars stained heavily for connective tissue with Mallory's trichrome and contained numerous pigment granules. Their shape was distorted with only a thin connective tissue capsule being present. In one ovary of the 8th specimen there was a second, easily recognizable, but regressed $\mathrm{CL}$ which was identified grossly as a small white area. Unfortunately, this specimen was received without a fetus so the exact stage of pregnancy could not be determined.

\section{Discussion}

The basic morphological features of the muskox uterus conformed to the ruminant pattern and closely paralleled descriptions given for sheep and goats (Eckstein \& Zuckerman, 1956; Nickel et al., 1979; Rowell, 1980).

Pigmentation of the uterine endometrium is common in sheep (Dellman \& Brown, 1976) and, to a lesser extent, goats (Lyngset, 1968). In sheep the degree of endometrial pigmentation shows considerable variation. In some sheep the uterine caruncles are only lightly pigmented: at the opposite extreme both the caruncles and the intercaruncular endometrium are intensely black. Pigment is found in both nulliparous and multiparous ewes and has been ascribed to the presence of melanocytes (Grant, 1933; Eckstein \& Zuckerman, 1956; Dellman \& Brown, 1976; Steven et al., 1981). In contrast, the pigment in the muskox uterus was confined to the caruncular depression, in particular the rim of this depression; was only found in parous tracts; and was associated with lipofuscins which occur in large amounts in the caruncular stroma. Although lipofuscins have commonly been referred to as age pigments (Toth, 1968) or wear-and-tear pigments (Dellman \& Brown, 1976), their precise origin and significance is poorly understood. Iron-free pigment granules in the cytotrophoblast of bats were described as lipofuscins derived from the envelopes of red cells (Wimsatt \& Gopalarkrishna, 1958). Hartroft \& Porta (1972) suggest that haemoglobin liberated at sites of haemorrhage in tissue containing saturated lipids is probably the cause of lipofuscin formation. Most domestic ruminants have uterine lipofuscins but lack the pattern of endometrial pigmentation found in the muskox uterus. It is possible that in the domestic species the lipofuscin deposits may not be as extensive as in the muskox or may originate from a different source and therefore possess slightly different properties. Grant (1933) describes similar pigment granules, different from melanin, in the ewe during the puerperium or following anoestrum. Because the pigment granules were found following pregnancy he suggested that they were of haematogenous

Fig. 14. Cross-section of a placentome showing fetal villi (a) interdigitating with maternal tissue (b). The specimen was taken from a gravid muskox uterus (with fetus and membranes) collected in March. Bar $=25 \mu \mathrm{m}$.

Fig. 15. Higher magnification of the tissue from the same specimen as in Fig. 14 showing large binucleate cells in the fetal trophectoderm (arrow). Bar $=10 \mu \mathrm{m}$.

Fig. 16. The ovary from a parous, non-pregnant muskox collected during the late breeding season showing two corpora lutea. Although the tissue was damaged by freezing, luteal structure $A$ is clearly smaller and morphologically different from luteal structure $B$. Bar $=2 \mathrm{~mm}$.

Fig. 17. Scar from a regressed CL found in the ovary adjacent to the gravid horn of a muskox collected in March. This structure was not identified macroscopically. It stained heavily for connective tissue with Masson's Trichrome and contained numerous pigmented structures. Bar $=1 \mathrm{~mm}$. 
origin. Hradecky (1983) described caruncular pigmentation occurring in a number of wild ruminants and attributed the pigmentation to previous pregnancies. Endometrial pigmentation in the muskox would appear to be a useful indicator of parity in field collected specimens.

The muscular band of tissue on the uterus also appears to be a morphological character associated with pregnancy, or more specifically, involution. At present no functional interpretation is evident.

The morphology of the gravid muskox tract was again typical of the ruminant pattern. The histological appearance of the placenta was similar to that of other ruminants and binucleate cells were present in the trophoblast (Wooding, 1982, 1984). Extravasated blood found near the base of the fetal villi suggests the existence of a small haemophagous organ, as has been described for sheep (Wimsatt, 1950; Steven, 1975) and goats (Harrison \& D'Silva, 1956). Electron microscopy of the haemophagus region in sheep indicates the absorption of maternal red blood cells by cells of the chorionic epithelium (Burton et al., 1976). These authors suggest this as one possible route for fetal absorption of iron. However, a more thorough investigation of muskox placentae with more adequately preserved material remains necessary.

Small, yellow, cyst-like structures were found in all the gravid tracts and are therefore not considered pathological. These cysts fit the description given by Jubb et al. (1985) of endometrial cysts, a condition which, in some ewes, is presumed to develop during the process of uterine involution.

The cervix exhibited some species individuality, particularly in the folds surrounding the external os. Lönnberg (1900a) suggested that these folds may function to retain spermatozoa in the vagina after copulation. The complex arrangement of the first and second annular ridges resembled that found in sheep (Bunch \& Ellsworth, 1981) and could impede artificial insemination.

There were many similarities between the ovaries of muskoxen and ruminants in general. The mature cows collected in August had substantially larger follicles than specimens collected later in the breeding season or during anoestrum. Preovulatory follicles measure $15-20 \mathrm{~mm}$ in cattle and approximately 6-8 mm in most breeds of sheep (Dellman \& Brown, 1976; Baker, 1982; Driancourt et al., 1985) and, since the size of the mature follicle is related to body size and is relatively constant for a species (Parkes, 1931), it is reasonable to expect that the 12 and $17 \mathrm{~mm}$ follicles observed in muskoxen in August were close to ovulation. Although Mossman \& Duke (1973) attribute no functional significance to 'Call-Exner' bodies, their preponderance in the granulosa of muskox follicles is noteworthy.

The signs of atresia in follicles at all stages of development is not surprising in view of the fact that about $85 \%$ of all follicles measuring more than $2 \mathrm{~mm}$ in diameter in cattle are undergoing atresia (Moor et al., 1984) and, in sheep, the rate of atresia in antral follicles varies between 45 and $60 \%$ (Driancourt \& Cahill, 1984).

Lactational anoestrus may explain the absence of cyclic activity in the ovaries of 2 cows collected in October. The presence of several CL in the ovaries of 2 other cows, apparently non-pregnant at the end of October, would suggest that these 2 cows were still cyclic, having already undergone at least 2 infertile oestrous cycles before collection.

The complete absence of a CL during late pregnancy places the muskox among the many species in which the CL regresses during pregnancy (Heap \& Flint, 1984). In the goat, the CL is essential throughout pregnancy and ovariectomy at any stage will result in abortion (Linzell \& Heap, 1968). In the ewe, pregnancy may be maintained after 50-60 days gestation without a CL. Morphologically however, the $\mathrm{CL}$ of the ewe is still evident at parturition, even though regressive changes are seen in gross section at 2-3 weeks pre partum (Grant, 1936; Cole \& Miller, 1935; Mossman \& Duke, 1973). Investigation of the endocrine and enzymic activities of the ovaries and placenta and the timing of CL regression will be necessary to establish their relative roles in the maintenance of pregnancy in this species. In this connection, the muskox may provide valuable information to add to that obtained from domestic ruminants in elucidating the importance of these organs in the evolution of viviparity (Porter et al., 1982). 
We thank the following people and organizations for extensive logistical support: A. Pijamini and the Grise Fiord Hunters and Trappers Association; T. Grant and W. Ulinder, Grise Fiord RCMP; Polar Continental Shelf Project, Department Energy Mines and Resources; The National Museum of Natural Science, Ethology Division and the Department of Renewable Resources, Government of The Northwest Territories. The project was supported by the Northern Scientific Training Program of the Department of Indian and Northern Affairs Canada; The National Sciences and Engineering Research Council, Canada (grant-in-aid of research No. A-6246) and The Arctic Institute of North America. J.R. was in receipt of a National Research Council Postgraduate Scholarship during the course of this work.

\section{References}

Alendal, E. (1971) Early sexual maturity and high fecundity in wild muskoxen in Norway. Fauna Oslo 24, 96-100.

Baker, T.G. (1982) Oogenesis and ovulation. In Reproduction in Mammals, Book 1, 2nd edn, pp. 17-45. Eds C. R. Austin \& R. V. Short. Cambridge University Press, Cambridge.

Betteridge, K.J., Eaglesome, M.D., Randall, G.C.B. \& Mitchell, D. (1980) Collection, description and transfer of embryos from cattle 10-16 days after oestrus. J. Reprod. Fert. 59, 205-216.

Bunch, T.D. \& Ellsworth, H.S. (1981) Gross anatomy of the ovine cervix. Int. Goat and Sheep Res. 1, 282-285.

Burton, G.J., Samuel, C.A. \& Steven, D.H. (1976) Ultrastructural studies of the placenta of the ewe: Phagocytosis of erythrocytes by the chorionic epithelium at the central depression of the cotyledon. Quart. Jl exp. Physiol. 61, 275-286.

Chisholm, M.J. \& Hopkins, C.Y. (1957) The normal $C_{17}$ fatty acids of muskox fat. Can. J. Chem. 35, 1434-1437.

Cole, H.H. \& Miller, R.F. (1935) Changes in the reproductive organs of the ewe with some data bearing on their control. Am. J. Anat. 57, 39-87.

Dellman, H.D. \& Brown, E.M. (1976) Textbook of Veterinary Histology. Lea and Febiger, Philadelphia.

Driancourt, M.A. \& Cahill, L.P. (1984) Preovulatory follicular events in sheep. J. Reprod. Fert. 71, $205-211$.

Driancourt, M.A., Cahill, L.P. \& Bindon, B.N. (1985) Ovarian follicular populations and preovulatory enlargement in Booroola and control Merino ewes. J. Reprod. Fert. 73, 93-107.

Drury, R.A.B. \& Wallington, E.A. (1967) Carleton's Histological Technique, 4th edn. Oxford University Press, New York.

Eckstein, P. \& Zuckerman, S. (1956) Morphology of the reproductive tract. In Marshall's Physiology of Reproduction, 3rd edn, Vol. 1, pp. 44-154. Ed. A. S. Parkes. Longmans, Green and Co., London.

Evans, H.E. \& Sack, W.O. (1973) Prenatal development of domestic and laboratory mammals growth curves, external features and selected references. Anat. Histol. Embryol. 2, 11-45.

Grant, R. (1933) The pigmentation of the uterine mucosa in the ewe. Veterinary Journal 89, 271-274.

Grant, R. (1936) Studies on the physiology of reproduction in the ewe. Part III. Gross changes in the ovaries. Trans. R. Soc. Edinb. pp. 36-47.
Gray, D.R. (1973) The social organization and behaviour of muskoxen (Ovibos moschatus) on Bathurst Island N.W.T. Ph.D. thesis, University of Alberta, Edmonton.

Guy, P.R. (1983) Conception dates and the Huggett and Widdas formula. Afr. J. Ecol. 21, 211-213.

Harrison, R.J. \& D'Silva, J.L. (1956) Uptake of radiopotassium by the uterus and placenta during the advancement of pregnancy in the rat and goat. In Ciba Fdn Colloq. Ageing, 2, Ageing in Transient Tissues, pp. 148-160. Churchill, London.

Hartroft, W.S. \& Porta, E.A. (1972) Observation and interpretation of lipid pigments (lipofuscins) in the pathology of laboratory animals. C.R.C. Crit. Rev. Toxicol. 1, 379-411.

Heap, R.B. \& Flint, A.P.F. (1984) Pregnancy. In Reproduction in Mammals, Book 3, 2nd edn, pp. 153-194. Eds C. R. Austin \& R. V. Short. Cambridge University Press, Cambridge.

Hradecky, P. (1983) Some uterine parameters in antelopes and a giraffe. Theriogenology 20, 491-498.

Huggett, A. St. G. \& Widdas, W.F. (1951) the relationship between mammalian fetal weight and conception age. J. Physiol., Lond. 114, 306-317.

Jubb, K.V.F., Kennedy, P.C. \& Palmer, N. (1985) Pathology of Domestic Animals, 3rd edn, Vol. 3, p. 367. Academic Press, New York.

Lillie, R.D. (1965) Histopathologic Technique and Practical Histochemistry. McGraw Hill Book Co., New York.

Linzell, J.L. \& Heap, R.B. (1968) A comparison of progesterone metabolism in the pregnant sheep and goat: sources of production and an estimation of uptake by some target organs. J. Endocr. 41, 433-438.

Lönnberg, E. (1900a) On the soft anatomy of the muskox (Ovibos moschatus). Proc. zool. Soc. Lond. 142-167.

Lönnberg, E. (1900b) On the structure and anatomy of the muskox (Ovibos moschatus). Proc. zool. Soc. Lond. 686-718.

Lyngset, O. (1968) Studies on reproduction in the goat. 1. Normal genital organs of the non-pregnant goat. Acta vet. scand. 9, 208-222.

Moody, P.D. (1958) Serological evidence on the relationships of the muskox. J. Mammal. 39, 554-559.

Moor, R.M., Kruip, Th.A.M. \& Green, D. (1984) Intraovarian control of folliculogenesis: limits to superovulation? Theriogenology 21, 103-116.

Mossman, H.W. \& Duke, K.L. (1973) Comparative 
Morphology of the Mammalian Ovary. University of Wisconsin Press, Madison.

Nickel, R., Schummer, A. \& Seiferle, E. (1979) The Viscera of the Domestic Mammals, 2nd edn. SpringerVerlag, New York.

Parkes, A.S. (1931) The reproductive process of certain mammals II. The size of the Graafian follicle at ovulation. Proc. R. Soc. B 109, 185-196.

Porter, D.G., Heap, R.B. \& Flint, A.P.F. (1982) Endocrinology of the placenta and the evolution of viviparity. J. Reprod. Fert., Suppl. 31, 113-138.

Putt, F.A. (1972) Manual of Histopathological Staining. John Wiley and Sons, New York.

Rowell, J. (1980) A preliminary study of reproductive anatomy in the female muskox (Ovibos moschatus). M.Sc. thesis, University of Ottawa.

Rowell, J. \& Betteridge, K.J. (1984) Reproductive anatomy in female muskoxen. Biol. Pap. Univ. Alaska. Spec. Rep. No. 4, p. 187, Abstr.

Sack, W.O. \& Ballantyne, J.H. (1965) Anatomical observations on a muskox calf (Ovibos moschatus) with particular reference to the thoracic and abdominal topography. Can. J. Zool. 43, 1033-1047.

Simpson, G.G. (1945) The principles of classification and the classification of mammals. Bull. Am. Mus. Nat. Hist. Vol. 85.

Smith, T.E. (1976) Reproductive behaviour and related social organization of the muskox on Nunivak Island. M.S. thesis, University of Alaska, Fairbanks.
Steven, D.H. (1975) Anatomy of the placental barrier. In Comparative Placentation, pp. 25-57. Ed. D. H. Steven. Academic Press, London.

Steven, D.H., Burton, G.J. \& Samuel, C.A. (1981) Histology and electron microscopy of sheep placental membranes. In Placental Transfer: Methods and Interpretations, pp. 11-34. Eds M. Young, R. D. H. Boyd, L. D. Longo \& G. Telegdy. W. B. Saunders, London.

Tener, J.S. (1965) Muskox in Canada. A Biological and Taxonomic Review. Queens Printer, Ottawa.

Tessaro, S., Rowell, J.E., Cawthorn, R. \& Latour, P. (1984) Banks Island Muskox Harvest, 1982. Biol. Pap. Univ. Alaska Spec. Rep. No. 4, 177-180.

Toth, S.E. (1968) The origin of lipofuscin age pigment. Expl Gerontol. 3, 19-30.

Wimsatt, W.A. (1950) New histological observations on the placenta of the sheep. Am. J. Anat. 87, 391-457.

Wimsatt, W.A. \& Gopalakrishna, A. (1958) Occurrence of a placental hematoma in the primitive sheathtailed bats (Emballonuridae), with observations on its structure, development and histochemistry. Am. J. Anat. 103, 35-67.

Wooding, F.B.P. (1982) The role of the binucleate cell in ruminant placental structure. J. Reprod. Fert., Suppl. 31, 31-39.

Wooding, F.B.P. (1984) Role of binucleate cells in fetomaternal cell fusion at implantation in the sheep. $\mathrm{Am}$. J. Anat. 170, 233-250.

Received 10 September 1986 